\title{
BMJ Open Patient information leaflets to reduce antibiotic use and reconsultation rates in general practice: a systematic review
}

\author{
Eefje G P M de Bont, Marleen Alink, Famke C J Falkenberg, Geert-Jan Dinant, \\ Jochen W L Cals
}

To cite: de Bont EGPM, Alink M, Falkenberg FCJ, et al. Patient information leaflets to reduce antibiotic use and reconsultation rates in general practice: a systematic review. BMJ Open 2015;5:e007612. doi:10.1136/bmjopen-2015007612

- Prepublication history and additional material is available. To view please visit the journal (http://dx.doi.org/ 10.1136/bmjopen-2015007612).

Received 8 January 2015 Revised 14 April 2015 Accepted 20 April 2015
CrossMark

Department of Family Medicine, CAPHRI School for Public Health and Primary Care, Maastricht University, Maastricht, The Netherlands

Correspondence to Eefje G P M de Bont; eefje.debont@ maastrichtuniversity.nl

\section{ABSTRACT}

Objective: Patients' knowledge and expectations may influence prescription of antibiotics. Therefore, providing evidence-based information on cause of symptoms, self-management and treatment is essential. However, providing information during consultations is challenging. Patient information leaflets could facilitate consultations by increasing patients' knowledge, decrease unnecessary prescribing of antibiotics and decrease reconsultations for similar illnesses. Our objective was to systematically review effectiveness of information leaflets used for informing patients about common infections during consultations in general practice.

\section{Design, setting and participants: We}

systematically searched PubMed/MEDLINE and EMBASE for studies evaluating information leaflets on common infections in general practice.

Two reviewers extracted data and assessed article quality.

Primary and secondary outcome measures: Antibiotic use and reconsultation rates.

Results: Of 2512 unique records, eight studies were eligible (7 randomised, controlled trials, 1 nonrandomised study) accounting for 3407 patients. Study quality varied from reasonable to good. Five studies investigated effects of leaflets during consultations for respiratory tract infections; one concerned conjunctivitis, one urinary tract infections and one gastroenteritis and tonsillitis. Three of four studies presented data on antibiotic use and showed significant reductions of prescriptions in leaflet groups with a relative risk (RR) varying from 0.53 (0.40 to $0.69)$ to 0.96 (0.83 to 1.11). Effects on reconsultation varied widely. One large study showed lower reconsultation rates (RR 0.70 (0.53 to 0.91 ), two studies showed no effect, and one study showed increased reconsultation rates (RR 1.53 (1.03 to 2.27)). Studies were too heterogenic to perform a meta-analysis.

Conclusions: Patient information leaflets during general practitioners consultations for common infections are promising tools to reduce antibiotic prescriptions. Results on reconsultation rates for similar symptoms vary, with a tendency toward fewer reconsultations when patients are provided with a leaflet. Use of information leaflets in cases of common infections should be encouraged. Their contributing

\section{Strengths and limitations of this study}

- To the best of our knowledge, this is the first systematic review to present the effectiveness of written information used during general practitioners consultations for common infections.

- This study used a broad search strategy for a complete and inclusive search.

- There was a great variety in study population samples (adults, children or both) and in primary and secondary outcomes; this heterogeneity limits the generalisability of results.

role in multifaceted interventions targeting management of common infections in primary care needs to further exploration.

\section{INTRODUCTION}

Overuse of antibiotics contributes to the growing problem of antimicrobial resistance and is widely recognised as a major public health problem. ${ }^{1}$ Eighty per cent of all antibiotics are prescribed in general practice. ${ }^{2}$ Most of these antibiotics are used for acute cough and respiratory tract infections, ${ }^{4}$ even though most of these infections are selflimiting and there is little benefit from treatment with antibiotics. ${ }^{5}$ Previous studies have showed that antibiotic prescription is strongly influenced by patients' expectations and that general practitioners (GPs) experience pressure from patients to prescribe antibiotics. ${ }^{67}$ The prescription of antibiotics is associated with increased reconsultation rates $^{8}$ and therefore, also increases GPs' workloads. Conveying evidence-based information to patients on the cause of symptoms, natural disease course and the expected benefits and harms of treatment is challenging for GPs in often time-pressured consultations. ${ }^{9}$

When asked, most patients appreciate written information ${ }^{10}$ and indicate they 
would be less likely to consult if they had more information about managing minor illnesses. ${ }^{11}{ }^{12}$ In addition, the use of written information may improve information retention up to $50 \%$ and patient satisfaction may improve. ${ }^{13}$ 14 Patients presenting with a common infection value information on selfmanagement strategies and expected duration of illness. The use of information leaflets to assist a consultation may be a useful tool to convey information, increase patient knowledge and possibly restrict antibiotic prescriptions. ${ }^{15}$

The aim of this systematic review is to study the effect of using patient information leaflets on antibiotic use and reconsultation rates in general practice consultations for common infections.

\section{METHODS}

\section{Literature search and study selection}

We systematically searched PubMed and EMBASE for original articles using the following Mesh terms: Pamphlets, Primary Health Care, General Practice, General Practitioners, Family Physicians, Family Practice. We then added the following free search terms: "handout", "leaflet", "booklet", "pamphlet", "flyer", "folder", "brochure", "general practice", "general practitioners", "family physicians", "family practice", "family medicine", and "primary health care" in April 2014 (see online supplementary appendix 1 for complete search string). We defined no further (language) restrictions, besides the exclusion of studies pertaining to dental practice. After merging records of both search engines, duplicate publications were removed.

We aimed to include randomised controlled and nonrandomised intervention trials in which the effect of a written information tool was studied during general practice consultations in developed countries. Information leaflets had to be given to patients in person by GPs or other GP staff such as nurses. The leaflet should contain information on the infection for which the patients consulted. Hence, we excluded studies with leaflets aimed at prevention, multifaceted studies in which no leaflet specific effect could be extracted, studies concerning decision aids, and studies on patient empowerment tools.

Two reviewers (FCJF, MA) independently screened the first 200 articles by title and abstract. Both reviewers selected the same studies. Thereafter, the remaining abstracts were selected by one reviewer and checked by another. Selected abstracts were discussed with a third reviewer (EGPMdB) and disagreement was resolved by consensus. Then, full text articles of the selected studies were assessed independently by two reviewers (FCJF, MA) for inclusion eligibility. Once again, all articles were discussed with the third reviewer (EGPMdB) and disagreement was resolved by consensus. We checked the reference lists of those selected articles for additional relevant publications.

\section{Data extraction}

A standardised form was used to identify relevant characteristics of the included studies: study methodology, population, setting, intervention and primary and secondary outcome measures. In case of missing methodological information, we tried to obtain this information by contacting the corresponding author. We contacted five authors of which two provided us with additional details.

\section{Methodological quality assessment}

We evaluated the methodological quality of included studies using the criteria of the Cochrane risk of bias tool (table 1). ${ }^{16}$ Two reviewers (FCJF, MA) independently assessed each paper and all articles were discussed with a third reviewer (EGPMdB). Disagreements were resolved by consensus. Each article was rated as "low risk of bias", "high risk of bias" or "unclear risk of bias".

\section{Outcomes and data analysis}

Primary outcomes were antibiotic prescription rates and antibiotic use, reconsultation during the same illness episode and intention to reconsult. Reported outcomes and percentages were recalculated as relative risks (RRs). A meta-analysis of aggregated data on the primary outcomes was predefined and planned, depending on the heterogeneity of the methodology and data. Other outcome measures reported by studies were narratively described when considered relevant.

\section{RESULTS}

\section{Study selection}

The search identified 2512 unique records of which 2490 were excluded following the screening of titles and abstracts. Of the remaining 23 full-text articles, seven studies met the inclusion criteria. One study was added following reference screening of included articles. This resulted in eight articles that became eligible for this review (see figure 1).

\section{Study characteristics}

Table 1 shows descriptive data of all included studies. In total, the studies included 3407 patients, both adults and children visiting GPs with their parents. Five studies examined the effect of a leaflet on the management of respiratory tract infections. ${ }^{17-21}$ Other leaflets contained information on conjunctivitis, ${ }^{22}$ urinary tract infections, ${ }^{23}$ gastroenteritis and tonsillitis. ${ }^{24}$ Two studies evaluated a combination of interventions in which an information leaflet was given together with another intervention such as delayed antibiotic prescribing. ${ }^{19} 22$ The main outcome measures of all studies are listed in table 1 .

\section{Study quality}

Study quality assessment using the Cochrane 'risk of bias' criteria are summarised in table $2 .{ }^{16}$ Seven of the 
Table 1 Characteristics of the included studies

\begin{tabular}{|c|c|c|c|c|c|c|c|}
\hline Author & Design & Population & Setting & $\begin{array}{l}\text { Intervention of } \\
\text { interest }\end{array}$ & Cointerventions & Primary outcomes & $\begin{array}{l}\text { Outcome } \\
\text { measurement }\end{array}$ \\
\hline $\begin{array}{l}\text { Agnew } \\
\text { et } a 1^{18}\end{array}$ & $\begin{array}{l}\text { Pragmatic, } \\
\text { non-randomised, } \\
\text { controlled trial }\end{array}$ & $\begin{array}{l}115 \text { patients (age not } \\
\text { specified) presenting with } \\
\text { RTI }\end{array}$ & $\begin{array}{l}4 \text { general } \\
\text { practitioners in } 1 \\
\text { teaching practice }\end{array}$ & $\begin{array}{l}\text { 1. Information } \\
\text { leaflet }(n=46) \\
\text { 2. No information } \\
\text { leaflet }(n=69)\end{array}$ & $\begin{array}{l}\text { Delayed antibiotic } \\
\text { prescriptions for all patients }\end{array}$ & Antibiotic use & $\begin{array}{l}\text { Telephone } \\
\text { questionnaire after } \\
\text { 10-14 days }\end{array}$ \\
\hline $\begin{array}{l}\text { Everitt } \\
\text { et } a P^{2}\end{array}$ & $\begin{array}{l}\text { Open, factorial, } \\
\text { randomised } \\
\text { controlled trial }\end{array}$ & $\begin{array}{l}307 \text { patients; adults and } \\
\text { children (aged } 1 \text { year or } \\
\text { more) presenting with acute } \\
\text { infective conjunctivitis }\end{array}$ & $\begin{array}{l}38 \text { general } \\
\text { practitioners and } \\
\text { practice nurses in } \\
30 \text { general } \\
\text { practices in } \\
\text { England }\end{array}$ & $\begin{array}{l}\text { 1. Information } \\
\text { leaflet }(n=150) \\
\text { 2. No information } \\
\text { leaflet }(n=157)\end{array}$ & $\begin{array}{l}\text { Antibiotics or not: } \\
\text { 1. Immediate antibiotics } \\
(n=104) \\
\text { 2. No antibiotics }(n=94) \\
\text { 3. Delayed antibiotics } \\
(n=109) \\
\text { An eye swab or not: } \\
\text { 1. Eye swab }(n=158) \\
\text { 2. No eye swab }(n=149)\end{array}$ & $\begin{array}{l}\text { 1. Severity of } \\
\text { symptoms } \\
\text { 2. Duration of } \\
\text { symptoms } \\
\text { 3. Belief in the } \\
\text { effectiveness of } \\
\text { antibiotics for } \\
\text { eye infections }\end{array}$ & $\begin{array}{l}\text { Validated patient } \\
\text { diaries after } 14 \text { days }\end{array}$ \\
\hline $\begin{array}{l}\text { Francis } \\
\text { et } a 1^{17}\end{array}$ & $\begin{array}{l}\text { Cluster randomised } \\
\text { controlled trial }\end{array}$ & $\begin{array}{l}558 \text { patients; children (aged } \\
6 \text { months to } 14 \text { years) } \\
\text { presenting with an acute RTI }\end{array}$ & $\begin{array}{l}\text { General } \\
\text { practitioners in } 61 \\
\text { general practices in } \\
\text { Wales and England }\end{array}$ & $\begin{array}{l}\text { 1. Interactive } \\
\text { booklet } \\
(n=274) \\
\text { 2. No booklet } \\
(n=284)\end{array}$ & $\begin{array}{l}\text { General practitioners } \\
\text { received online training for } \\
\text { the use of the booklet in } \\
\text { which the use of certain } \\
\text { communication skills was } \\
\text { facilitated }\end{array}$ & $\begin{array}{l}\text { Reconsultation } \\
\text { rates }\end{array}$ & $\begin{array}{l}\text { Telephone } \\
\text { questionnaire with the } \\
\text { child's parent or } \\
\text { guardian after } 14 \text { days }\end{array}$ \\
\hline $\begin{array}{l}\text { Gauld } \\
\text { et } a P^{33}\end{array}$ & $\begin{array}{l}\text { Randomised } \\
\text { controlled trial }\end{array}$ & $\begin{array}{l}62 \text { patients; female adults } \\
\text { (aged } 15-64 \text { years) } \\
\text { presenting with symptoms of } \\
\text { urinary tract infection for } \\
\text { whom the doctor prescribed } \\
\text { an antibiotic }\end{array}$ & $\begin{array}{l}18 \text { general } \\
\text { practitioners in } 8 \\
\text { general practices in } \\
\text { England }\end{array}$ & $\begin{array}{l}\text { 1. Information } \\
\text { leaflet }(n=30) \\
\text { 2. No information } \\
\text { leaflet }(n=32)\end{array}$ & $\begin{array}{l}\text { Standard verbally advice at } \\
\text { the end of the consultation }\end{array}$ & $\begin{array}{l}\text { 1. Recall of } \\
\text { information } \\
\text { 2. Compliance with } \\
\text { the prescribed } \\
\text { course of } \\
\text { antibiotics }\end{array}$ & $\begin{array}{l}\text { Interview in the } \\
\text { patient's home after } 4 \\
\text { or } 5 \text { days }\end{array}$ \\
\hline Little et $a l^{19}$ & $\begin{array}{l}\text { Factorial } \\
\text { randomised } \\
\text { controlled trial }\end{array}$ & $\begin{array}{l}807 \text { patients; adults and } \\
\text { children (aged } 3 \text { years or } \\
\text { more) presenting with acute, } \\
\text { uncomplicated lower RTI }\end{array}$ & $\begin{array}{l}37 \text { physicians in } \\
\text { England }\end{array}$ & $\begin{array}{l}\text { 1. Information } \\
\text { leaflet }(n=405) \\
\text { 2. No information } \\
\text { leaflet }(n=402)\end{array}$ & $\begin{array}{l}\text { Antibiotics or not: } \\
\text { 1. Immediate antibiotics } \\
(n=262) \\
\text { 2. No antibiotics }(n=273) \\
\text { 3. Delayed antibiotics } \\
(n=272)\end{array}$ & $\begin{array}{l}\text { 1. Severity of } \\
\text { symptoms } \\
\text { 2. Duration of } \\
\text { symptoms }\end{array}$ & $\begin{array}{l}\text { Validated patient } \\
\text { diaries after } 1 \text { month }\end{array}$ \\
\hline $\begin{array}{l}\text { Macfarlane } \\
\text { et } a \text { PO }^{\circ}\end{array}$ & $\begin{array}{l}\text { Single blind } \\
\text { randomised } \\
\text { controlled trial }\end{array}$ & $\begin{array}{l}1014 \text { patients; adults (aged } \\
16 \text { years or more) presenting } \\
\text { with acute lower RTI }\end{array}$ & $\begin{array}{l}76 \text { general } \\
\text { practitioners }\end{array}$ & $\begin{array}{l}\text { 1. Information } \\
\text { leaflet }(n=505) \\
\text { 2. No information } \\
\text { leaflet }(n=501)\end{array}$ & - & $\begin{array}{l}\text { Reconsultation } \\
\text { rates }\end{array}$ & $\begin{array}{l}\text { General practitioners' } \\
\text { records after } 1 \text { month }\end{array}$ \\
\hline $\begin{array}{l}\text { Macfarlane } \\
\text { et } a P^{1}\end{array}$ & $\begin{array}{l}\text { Nested, single blind, } \\
\text { randomised } \\
\text { controlled trial }\end{array}$ & $\begin{array}{l}259 \text { patients; adults (aged } \\
16 \text { years or more) presenting } \\
\text { with acute lower RTI }\end{array}$ & $\begin{array}{l}\text { General } \\
\text { practitioners in } 3 \\
\text { general practices in } \\
\text { England }\end{array}$ & $\begin{array}{l}\text { 1. Information } \\
\text { leaflet }(n=106) \\
\text { 2. No information } \\
\text { leaflet }(n=106)\end{array}$ & $\begin{array}{l}\text { Delayed prescription for all } \\
\text { patients } \\
\text { Standard verbal information }\end{array}$ & $\begin{array}{l}\text { 1. Antibiotic use } \\
\text { 2. Reconsultation } \\
\text { rates }\end{array}$ & $\begin{array}{l}\text { Patient diaries and } \\
\text { telephone interviews } \\
\text { after } 1 \text { month and } \\
1-2 \text { weeks, respectively }\end{array}$ \\
\hline $\begin{array}{l}\text { Sustersic } \\
\text { et } a R^{4}\end{array}$ & $\begin{array}{l}\text { Cluster randomised } \\
\text { controlled trial }\end{array}$ & $\begin{array}{l}400 \text { patients; adults and } \\
\text { children presenting with } \\
\text { gastroenteritis or tonsillitis }\end{array}$ & $\begin{array}{l}24 \text { general } \\
\text { practitioners }\end{array}$ & $\begin{array}{l}\text { 1. Information } \\
\text { leaflet }(n=183) \\
\text { 2. No information } \\
\text { leaflet }(=217)\end{array}$ & - & Patient behaviour & $\begin{array}{l}\text { Telephone } \\
\text { questionnaire with the } \\
\text { patient or the adult } \\
\text { accompanying the child } \\
\text { after } 10-15 \text { days } \\
\end{array}$ \\
\hline
\end{tabular}

RTI, respiratory tract infection. 


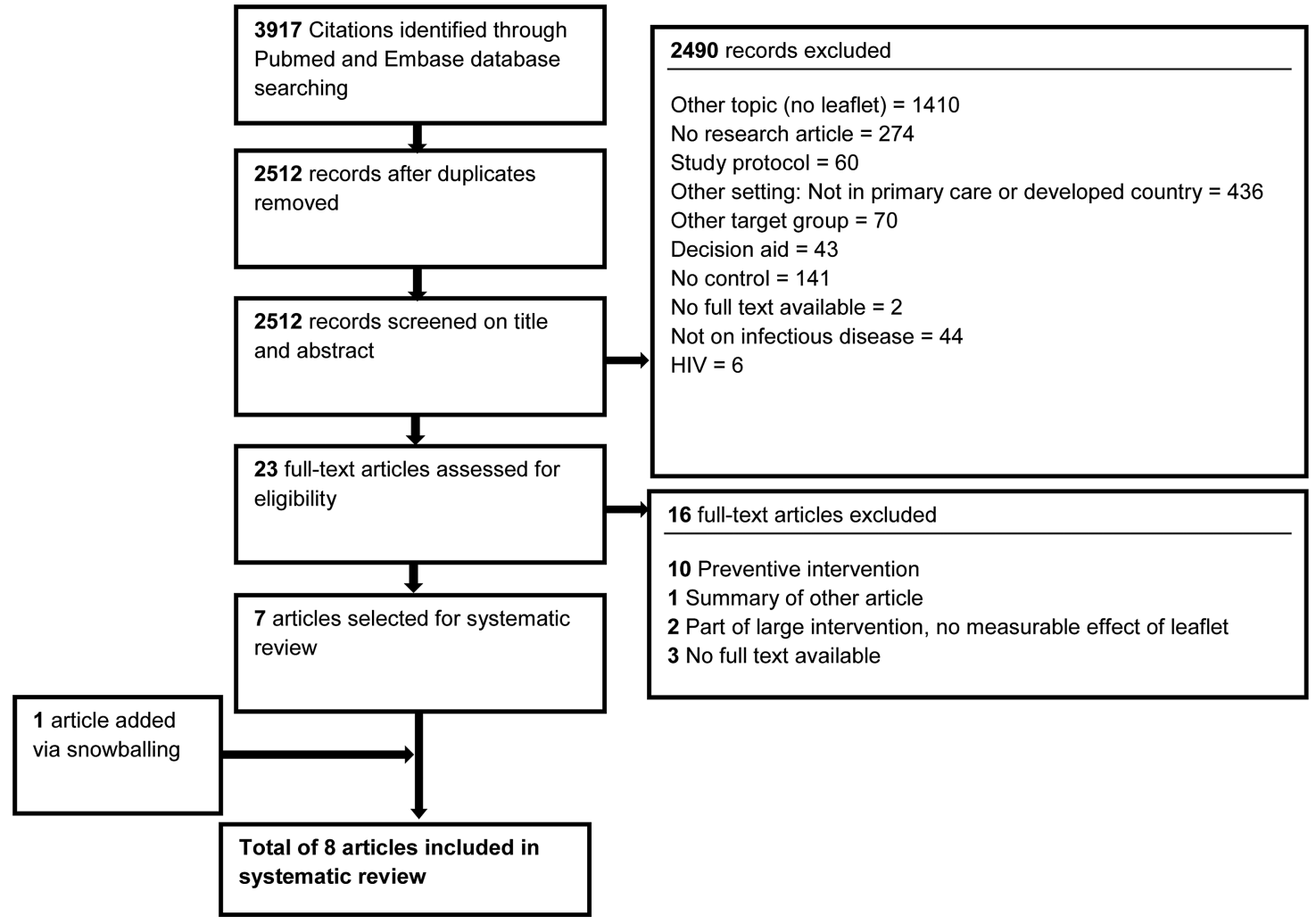

Figure 1 Flow chart for the study selection.

eight studies were randomised trials. In general, there was a minimal risk of allocation bias. We identified a high risk of bias for all studies for failing to blind participants and personnel. Overall, the study of Francis $e t a l^{17}$ had the lowest risk of bias. Agnew et $a l^{18}$ had the highest risk of bias. More detailed information about study quality is outlined in online supplementary appendix 2.

\section{Results of studies}

\section{Primary outcomes}

Six of the eight studies described one or more of our predefined outcomes of interest (table 3). ${ }^{17-22} \mathrm{We}$ decided not to perform a meta-analysis since the methodology, study populations and chosen outcome measures were too heterogenic to pool relevant data (table 1).

Two large studies, Francis et $a l^{17} \quad(\mathrm{n}=558)$ and Macfarlane et $a t^{20} \quad(\mathrm{n}=1014)$, determined the effect of an information leaflet for respiratory tract infections on antibiotic prescription. Francis $e t a l$ s study, ${ }^{17}$ which was of high quality, assessed the effect of a booklet for childhood respiratory infections. Patients managed by a GP using the booklet were exposed to significantly less antibiotic prescription (RR $0.47,95 \%$ CI 0.36 to 0.64 ). In Macfarlane et $a l,{ }^{20}$ the effect of a booklet among adults with lower respiratory tract symptoms was investigated. The booklet led to a non-significant reduction in antibiotic prescription (RR $1.15,95 \%$ CI 0.89 to 1.48 ). Four studies focused on the effect of patient information

Table 2 Risk of bias (summary) of the included studies assessed by Cochrane's risk of bias tool

\begin{tabular}{|c|c|c|c|c|c|c|}
\hline Author & $\begin{array}{l}\text { Sequence } \\
\text { generation }\end{array}$ & $\begin{array}{l}\text { Allocation } \\
\text { concealment }\end{array}$ & $\begin{array}{l}\text { Blinding } \\
\text { participants } \\
\text { and personnel }\end{array}$ & $\begin{array}{l}\text { Blinding of } \\
\text { outcome } \\
\text { assessors }\end{array}$ & $\begin{array}{l}\text { Incomplete } \\
\text { outcome } \\
\text { data }\end{array}$ & $\begin{array}{l}\text { Selective } \\
\text { outcome } \\
\text { reporting }\end{array}$ \\
\hline Agnew et $a l^{18}$ & High risk & Low risk & High risk & Unclear risk & Unclear risk & Low risk \\
\hline Everitt et $a R^{2}$ & Low risk & Low risk & High risk & High risk & Low risk & Low risk \\
\hline Francis et $a l^{17}$ & Low risk & Low risk & High risk & Low risk & Low risk & Low risk \\
\hline Gauld et $a^{P^{3}}$ & Unclear risk & Unclear risk & High risk & Low risk & Low risk & Low risk \\
\hline Little et $a l^{19}$ & Low risk & Low risk & High risk & High risk & Low risk & Low risk \\
\hline Macfarlane et $a^{20}$ & Unclear risk & Low risk & High risk & Unclear risk & Low risk & Low risk \\
\hline Macfarlane et $a^{21}$ & Unclear risk & Low risk & High risk & High risk & Low risk & Low risk \\
\hline Sustersic et $a^{R^{4}}$ & Low risk & Low risk & High risk & Unclear risk & Low risk & Low risk \\
\hline
\end{tabular}


Table 3 Effect of patient information leaflets on antibiotic prescribing, antibiotic use, reconsultation and intention to reconsult in respiratory tract infections

\begin{tabular}{|c|c|c|c|c|}
\hline & \multicolumn{2}{|l|}{ Antibiotics } & \multicolumn{2}{|l|}{ Reconsultation } \\
\hline & $\begin{array}{l}\text { Antibiotic } \\
\text { prescribing } \\
\text { RR (95\% Cl) }\end{array}$ & $\begin{array}{l}\text { Antibiotic use } \\
\text { RR }(95 \% \mathrm{Cl})\end{array}$ & $\begin{array}{l}\text { Reconsultation } \\
\text { rate } \\
\text { RR }(95 \% \mathrm{Cl})\end{array}$ & $\begin{array}{l}\text { Intention to } \\
\text { reconsult } \\
\text { RR (95\% Cl) }\end{array}$ \\
\hline $\begin{array}{l}\text { Agnew et } a l^{18} \\
n=115 \\
\text { Respiratory tract infection }\end{array}$ & - & 0.6 (0.42 to 0.86$)$ & - & - \\
\hline $\begin{array}{l}\text { Everitt et } a^{2} \\
\mathrm{n}=307 \\
\text { Acute conjunctivitis }\end{array}$ & - & - & - & 0.86 (0.66 to 1.12$)$ \\
\hline $\begin{array}{l}\text { Francis et al }{ }^{17} \\
\mathrm{n}=558 \\
\text { Respiratory tract infection }\end{array}$ & 0.47 (0.36 to 0.64$)$ & 0.53 (0.40 to 0.69$)$ & $0.80(0.52 \text { to } 1.21)^{*}$ & 0.72 (0.63 to 0.82$)$ \\
\hline $\begin{array}{l}\text { Little et al }{ }^{19} \\
\mathrm{n}=807 \\
\text { Respiratory tract infection }\end{array}$ & - & 0.96 (0.83 to 1.11$)$ & $1.53(1.03$ to 2.27$) \dagger$ & - \\
\hline $\begin{array}{l}\text { Macfarlane et afO } \\
n=1014 \\
\text { Respiratory tract infection }\end{array}$ & $1.15(0.89$ to 1.48$)$ & - & $0.70(0.53$ to 0.91$) \dagger$ & - \\
\hline $\begin{array}{l}\text { Macfarlane et } a^{P^{1}} \\
\mathrm{n}=259 \\
\text { Respiratory tract infection }\end{array}$ & - & 0.76 (0.59 to 0.97$)$ & $0.79(0.38$ to 1.67$) \dagger$ & - \\
\hline $\begin{array}{l}\text { Expressed as the risk of the o } \\
\text { managed in the control group } \\
{ }^{*} \text { Within } 2 \text { weeks. } \\
\text { tWithin } 1 \text { month. } \\
\text { RR, relative risk. }\end{array}$ & $\begin{array}{l}\text { for those patients } \\
\text { flet). }\end{array}$ & $d$ by patient leaflets & ed with the risk of the & me for patients \\
\hline
\end{tabular}

leaflets on actual antibiotic use as reported by patients. ${ }^{17-19}{ }^{21}$ Francis $e t a l^{17}$ showed a significant reduction in antibiotic use in the intervention group (RR $0.53,95 \%$ CI 0.40 to 0.69$)$. Three studies - Agnew et $a l^{18}$ $(\mathrm{n}=115)$, Little et $a l^{19}(\mathrm{n}=807)$, and Macfarlane $e t a l^{21}$ $(n=259)$ - described the use of patient information leaflets in addition to delaying antibiotic prescription for a respiratory tract infection. ${ }^{18} 1921$ This caused a significant reduction of antibiotic use in one study examining the effect of a booklet among 259 previously healthy adults presenting with acute bronchitis (RR 0.76 (95\% CI 0.59 to 0.97$)) .{ }^{21}$ It also led to fewer prescriptions in a study among 115 patients where information leaflets on antibiotics were combined with a delay in antibiotic prescription 0.6 (95\% CI 0.42 to 0.86$).{ }^{18}$ Little $e t a l \mathrm{~s}^{19}$ study among patients aged 3 years or older, who had signs of an acute, uncomplicated lower respiratory tract infection, showed a non-significant decrease in antibiotic use (RR $0.96,95 \%$ CI 0.83 to 1.11 ).

Four studies evaluated reconsultation rates. ${ }^{17}{ }^{19-21} \mathrm{~A}$ large study from Macfarlane $e t a t^{20}$ showed a significant reduction (RR $0.70,95 \%$ CI 0.53 to 0.91 ). ${ }^{20}$ Two other studies by Francis et $a l^{17}$ and Macfarlane $e t a l^{21}$ did not show a significant reduction in reconsultation for the same illness episode after providing an information leaflet ( RR 0.8 (95\% CI 0.52 to 1.21) and 0.79 (95\% 0.38 to 1.67$)$, respectively). Little $e$ e $a l \mathrm{~s}^{19}$ study showed a significant increase in attendance in the month after index consultations in the intervention group (RR 1.53 (95\% CI 1.03 to 2.27$)$ ).

In addition to reconsultation rates, some studies also focused on patients' intention to reconsult for similar illnesses. Francis et $a l^{17}$ showed a significant reduction in intention to reconsult among parents in the intervention group (RR $0.72,95 \%$ CI 0.63 to 0.82 ) while Everitt et $a l^{22}$ studying the effect of a conjunctivitis leaflet in a study population of 307 adult and paediatric participants, found a nonsignificant reduction in the intention to reconsult for future similar symptoms (RR $0.86,95 \%$ CI 0.66 to 1.12 ).

\section{Other outcome measures}

Everitt $e t a l^{22}$ showed that patient information leaflets had a positive effect on patient satisfaction. Patients in the intervention group were more satisfied with the GP consultation and provided information. Other studies assessed patients' beliefs in the effectiveness of antibiotics ${ }^{19} 22$ and patients' worries. ${ }^{17}{ }^{22}$ However, they did not show any significant effects. In the study by Sustersic et $a l^{24}$ among 400 French adults and children consulting a GP with gastroenteritis or tonsillitis, patients and parents who received a leaflet showed behaviour significantly closer to that recommended by the leaflet. Francis $e t a l^{17}$ investigated the effect of an information booklet on patient enablement, but did not find a significant increase. One small study dated from 1981 concerned urinary tract infections. The study investigated if 
a patient education leaflet given in addition to a prescribed course of antibiotics could increase compliance rates; no significant improvements were found..$^{23}$

\section{DISCUSSION}

\section{Main findings}

The findings of this review suggest that the use of information leaflets in general practice consultations are effective in reducing antibiotic prescription by GPs, and actual antibiotic use by patients and their intention to reconsult for future similar episodes of illness. It is unclear whether information leaflets also actually affect reconsultation rates.

\section{Relevance and comparison with other studies}

There are many reasons and indications for which a GP might consider handing out a patient information leaflet. A study showed that patient information leaflets are appreciated by patients because these have the potential to enhance patient-physician interaction, health-related knowledge and self-management. ${ }^{25}$ This makes patient information leaflets attractive in general. However, these might not be suitable for every indications, since there are also studies that show that leaflets, for example, about medication side effects, are not used by many patients and have a negative effect in the patients that do use them by increasing anxiety. ${ }^{26}$ Nevertheless, since acute infections are so common, mostly self-managed and the patient-doctor interaction considered as an important determinant of antibiotic prescriptions, we believe that these leaflets do have potential for this indication when used interactively in the consulting room.

Antibiotic use was reduced significantly in three of four studies. The same tendency was seen for antibiotic prescription; there was a significant reduction of prescriptions in one study ${ }^{17}$ and a non-significant reduction in another study. ${ }^{20}$ Seven studies focused on self-limiting infections, which often do not require any antibiotic treatment. Previous studies emphasised that antibiotic prescription by GPs is strongly influenced by patient expectations of antibiotics, and consequently GPs sense patient pressure to prescribe. ${ }^{15}$ This potentially leads to an antibiotic prescription in two of three consultations despite the lack of a true indication. ${ }^{6}$ Overuse of antibiotics contributes to the growing problem of drug resistance. $^{27}$ Adequate patient education is, therefore, required to adjust the widespread belief among patients that antibiotics are a solution for all infections. In addition, facilitation of communication is necessary to prevent GPs from feeling pressurised to prescribe antibiotics when patients do not expect a prescription. A simple intervention like an information leaflet might be a very promising tool to facilitate this dialogue and to reduce unnecessary antibiotic prescriptions.

The studies of Francis $e t a l^{17}$ and Everitt $e t a l^{22}$ examined the effect of patient information leaflets on future consultation behaviour and showed a significant and a non-significant reduction, respectively, in patients' and parents' intention to reconsult. Actual reconsultation rates were significantly lower only in the leaflet intervention group of the largest study, with a RR of $0.70(0.53$ to 0.90$){ }^{6}$ This reduction in reconsultation and intention to reconsult could be caused by leaflets containing advice on self-management and self-treatment strategies. Interestingly, one of the studies showed that patient information leaflets also reduced the number of consultations by other household members who acquired the same infection. ${ }^{24}$ If consultation rates can be lowered without decreasing patients' satisfaction and quality of care, this can lead to a reduction in the number of GP consultations. Yet again, one study showed a significant increase in consultation rates in the leaflet group. ${ }^{19}$ In this case, the leaflet might have triggered patients to recognise signs and symptoms described in the information leaflet, which could lead to additional consultations to obtain advice for symptoms such as ongoing fever or shortness of breath.

Many previous studies investigated the effect of patient education materials. However, the effect of those education materials was mostly assessed in multiple clinical settings and focused on conditions other than common infections. Our search yielded many studies on smoking cessation, asthma self-management, coping studies on cardiovascular diseases and musculoskeletal problems such as lower back pain. Many of these studies were included in a systematic review evaluating the effect of information materials on low back pain. Variable results were found on reconsultation rates and behavioural improvement. ${ }^{28-30}$ One interventional trial found significant reductions in solicitation of emergency care for non-urgent care of children after providing the parents with educational leaflets. ${ }^{31}$ In another study, families receiving a preventive information leaflet made fewer unnecessary visits for respiratory tract infections. ${ }^{32} \mathrm{~A}$ Dutch study investigated the effect of a leaflet on minor illnesses handed out by GPs to their patients. A significant decrease in the number of consultations for minor illnesses was seen in the entire population. ${ }^{33}$

\section{Strength and limitations}

The quality of evidence in the included articles varied from reasonably good to good. All studies scored high risk of "blinding of participants and personnel". This was unsurprising since the nature of a patient information leaflet makes it relatively impossible to blind both GPs and patients. Therefore, all studies had an openlabel design.

Three studies scored high risk in blinding of outcome assessors. ${ }^{19} 2122$ This was caused due to the fact that patients wrote down their perceptions and symptoms in a patient diary at home. However, we believe the introduction of an independent outcome assessor to write down this subjective information is not likely to lower the risk of reporting bias. 
Most studies performed an adequate randomisation. Two studies performed cluster randomisation at the practice level. ${ }^{17}{ }^{24}$ Cluster randomisation could hypothetically increase the risk of postrandomisation recruitment bias, as GPs are aware of their assignment to an intervention group and are able to influence the selection of patients. However, the strength of this strategy is that it avoids contamination between control and intervention groups.

There were some other potential threats to validity. Two studies had a small study population, which could have influenced the results and led to insufficient power to find a significant difference in antibiotic prescriptions and reconsultation rates. ${ }^{18} 23$ Regarding the setting, all studies took place in general practices in Western European countries. Therefore, we do not know to what extent these results are generalisable to non-Western primary care settings. One study was carried out in a training practice, and we are not sure whether this is completely comparable to regular general practices. ${ }^{18}$ For example, GPs working in a training practice might be more aware of their communication skills than GPs working in a regular practice.

One explanation for the differences in the effects of the information leaflets could be that in several studies the information leaflet was handed out by GPs at the end of the consultation, or handed over in a sealed envelope, without further explanation. In one study, the booklet was introduced more interactively during the consultation. ${ }^{17}$ By discussing the information, it is guaranteed that patients are exposed to the leaflet's content. In our opinion, this interactive approach could facilitate more effective communication and GPs may address potential misconceptions about antibiotic prescriptions, thereby enhancing the quality of a consultation and reinforcing the intended effect: to improve the knowledge among patients and prescribe fewer antibiotics. This might be one of the reasons why the intervention in this study led to fewer antibiotic prescriptions and intention to reconsult, while in other studies it had no effect.

A similar approach was taken in a large multinational European trial with 4264 patients in which important reductions in antibiotic prescriptions for respiratory-tract infections were achieved by using an interactive booklet cutting across language and cultural boundaries. ${ }^{34}$ This study was not included in our systematic review as the use of that interactive booklet was part of a multifaceted complex communication process during a training intervention. Hence, the effect of the booklet alone could not be disentangled.

To the best of our knowledge, this is the first systematic review to present the effectiveness of written information used during GP consultations for common infections. Since the aim of this study was not to investigate the effect of preventive leaflets, we only included leaflets that were handed over in person by a GP or medical employee and contained information on the reason for the patient consult. In our opinion, the active use of a leaflet during consultation and the fact that it relates to an acute problem increases the chance that patients will actually read the leaflet and consider it relevant. Owing to this fact, studies were excluded because they were preventive or seen as educational and not related to a consultation.

There are certain limitations in this review that should be recognised. There was a great variety in study population samples (adults, children or both) and in the primary and secondary outcomes, which were measured both objectively and subjectively. to this heterogeneity, one of the major difficulties of this review is generalising the evidence of included studies. We did not perform a heterogeneity analysis because of the heterogeneity in methodologies and study populations. We believe that, in this case, methodological heterogeneity is superior to statistical heterogeneity. However, RRs and applied CIs were calculated for our outcomes of interest to compare and interpret outcome data.

\section{Implications for practice}

Patient information leaflets are generally assumed to have several advantages: saving time in consultation, providing evidence-based patient information and stimulating patients to follow advice correctly. ${ }^{35}$ To make these leaflets accessible to the broad public, the level of (health) literacy should be considered. The usage of plain language reinforced with pictorial representations increases the utilisation of educational material. ${ }^{36} \mathrm{We}$ also acknowledge that a subgroup of patients presenting in general practice do need antibiotics to treat serious infections. Patient information leaflets should, therefore, also provide patients with information on when they should consult because they might need treatment.

This systematic review indicates that the use of patient information leaflets may be a promising tool to reduce antibiotic use. Therefore, the use of patient information leaflets for common infections in general practice should be encouraged. Included studies mostly focused on the immediate effects of leaflets on reconsultation rates. The use of these patient information leaflets might also decrease consultation rates for similar illnesses in the future. To investigate if such an effect exists, a long-term follow-up trial on a large cohort of patients in general practice is necessary. Since communication is the cornerstone of general practice consultation and patients can only typically recall two instructions given in a consultation, ${ }^{37}$ further studies into the effectiveness of leaflets for conditions other than common infections should be propagated.

\section{CONCLUSIONS}

Overall, this review provides evidence that the use of patient information leaflets on common infections during GP consultation may effectively reduce antibiotic prescriptions and antibiotic use and patients' intention to reconsult. Therefore, GPs are encouraged to actively use patient information leaflets during consultations for common infections. 
Twitter Follow Eefje de Bont at @eefje_de_bont

Contributors All authors designed the study strategy, including the search terms and inclusion and exclusion criteria. MA, FCJF, and EGPMdB performed the search, study selection and data extraction. All authors agreed on the quality assessment of included papers and interpretation of results by discussion. MA, FF, and EGPMdB drafted the article, which JWLC and G-JD revised. All authors approved the final version of the manuscript.

Funding The Netherlands Organisation for Health Research and Development (ZonMW grant 836-021022) funded this study. Jochen Cals is supported by a Veni-grant (91614078) of the Netherlands Organisation for Health Research and Development (ZonMw).

Competing interests None declared.

Provenance and peer review Not commissioned; externally peer reviewed.

Data sharing statement All data, including full search terms and eligibility criteria, are available either in the article or as online supplementary material submitted with this manuscript.

Open Access This is an Open Access article distributed in accordance with the Creative Commons Attribution Non Commercial (CC BY-NC 4.0) license, which permits others to distribute, remix, adapt, build upon this work noncommercially, and license their derivative works on different terms, provided the original work is properly cited and the use is non-commercial. See: http:// creativecommons.org/licenses/by-nc/4.0/

\section{REFERENCES}

1. Bronzwaer SL, Cars O, Buchholz U, et al. A European study on the relationship between antimicrobial use and antimicrobial resistance. Emerg Infect Dis 2002;8:278-82.

2. Butler CC, Hillier S, Roberts Z, et al. Antibiotic-resistant infections in primary care are symptomatic for longer and increase workload: outcomes for patients with E. coli UTIs. Br J Gen Pract 2006;56:686-92

3. Petersen I, Johnson AM, Islam A, et al. Protective effect of antibiotics against serious complications of common respiratory tract infections: retrospective cohort study with the UK General Practice Research Database. BMJ 2007;335:982

4. Monto AS. Epidemiology of viral respiratory infections. Am J Med 2002;112(Suppl 6A):4S-12S.

5. Smith SM, Fahey T, Smucny J, et al. Antibiotics for acute bronchitis. Cochrane Database Syst Rev 2014;(3):CD000245.

6. Macfarlane J, Holmes W, Macfarlane R, et al. Influence of patients expectations on antibiotic management of acute lower respiratory tract illness in general practice: questionnaire study. BMJ 1997;315:1211-14.

7. Howie JG. Clinical judgement and antibiotic use in general practice. BMJ 1976;2:1061-4.

8. Little P, Gould C, Williamson I, et al. Reattendance and complications in a randomised trial of prescribing strategies for sore throat: the medicalising effect of prescribing antibiotics. BMJ 1997;315:350-2.

9. Butler CC, Rollnick S, Pill R, et al. Understanding the culture of prescribing: qualitative study of general practitioners' and patients' perceptions of antibiotics for sore throats. BMJ 1998;317:637-42.

10. Kenny T, Wilson RG, Purves IN, et al. A PIL for every ill? Patient information leaflets (PILs): a review of past, present and future use. Fam Pract 1998;15:471-9.

11. Moult B, Franck LS, Brady $\mathrm{H}$. Ensuring quality information for patients: development and preliminary validation of a new instrument to improve the quality of written health care information. Health Expect 2004;7:165-75

12. McCarthy K, Prentice P. Commissioning health education in primary care. BMJ 2006;333:667-8.

13. Little $\mathrm{P}$, Dorward M, Warner G, et al. Randomised controlled trial of effect of leaflets to empower patients in consultations in primary care. BMJ 2004;328:441.
14. Sustersic $M$, Voorhoeve $M$, Menuret $H$, et al. Fiches d'information pour les patients: quel intérêt? L'étude EDIMAP. La Rev méd gén 2010;276:332-9.

15. Mills ME, Sullivan K. The importance of information giving for patients newly diagnosed with cancer: a review of the literature. J Clin Nurs 1999;8:631-42.

16. Higgins JPT, Green S eds. Cochrane handbook for systematic reviews of interventions. The Cochrane Collaboration, 2011:187-241.

17. Francis NA, Butler CC, Hood K, et al. Effect of using an interactive booklet about childhood respiratory tract infections in primary care consultations on reconsulting and antibiotic prescribing: a cluster randomised controlled trial. BMJ 2009;339:374-6.

18. Agnew J, Taaffe M, Darker $\mathrm{C}$, et al. Delayed prescribing of antibiotics for respiratory tract infections: use of information leaflets. Ir Med J 2013;106:243-4

19. Little P, Rumsby K, Kelly J, et al. Information leaflet and antibiotic prescribing strategies for acute lower respiratory tract infection: a randomized controlled trial. JAMA 2005;293:3029-35.

20. Macfarlane JT, Holmes WF, Macfarlane RM. Reducing reconsultations for acute lower respiratory tract illness with an information leaflet: a randomized controlled study of patients in primary care. Br J Gen Pract 1997;47:719-22.

21. Macfarlane J, Holmes W, Gard P, et al. Reducing antibiotic use for acute bronchitis in primary care: blinded, randomised controlled trial of patient information leaflet. BMJ 2002;324:91-4.

22. Everitt HA, Little PS, Smith PWF. A randomised controlled trial of management strategies for acute infective conjunctivitis in general practice. BMJ 2006;333:321-4

23. Gauld VA. Written advice: compliance and recall. J R Coll Gen Pract 1981;31:553-6.

24. Sustersic M, Jeannet E, Cozon-Rein L, et al. Impact of information leaflets on behavior of patients with gastroenteritis or tonsillitis: a cluster randomized trial in French primary care. J Gen Intern Med 2013:28:25-31.

25. Moerenhout T, Borgermans L, Schol S, et al. Patient health information materials in waiting rooms of family physicians: do patients care? Patient Prefer Adherence 2013;7:489-97.

26. Vinker S, Eliyahu V, Yaphe J. The effect of drug information leaflets on patient behavior. Isr Med Assoc J 2007;9:383-6.

27. Health Do. UK 5 Year Antimicrobial Resistance (AMR) Strategy 2013-2018-progress report. (April). https://www.gov.uk/ government/uploads/system/uploads/attachment data/file/385733/ UK_AMR_annual_report.pdf (accessed Apr 2015).

28. Hazard $\mathrm{RG}$, Reid $\mathrm{S}$, Haugh LD, et al. A controlled trial of an educational pamphlet to prevent disability after occupational low back injury. Spine 2000;25:1419-23.

29. Henrotin YE, Cedraschi C, Duplan B, et al. Information and low back pain management: a systematic review. Spine 2006;31:E326-34.

30. Roberts L, Little P, Chapman J, et al. The back home trial: general practitioner-supported leaflets may change back pain behavior. Spine 2002;27:1821-8.

31. Yoffe SJ, Moore RW, Gibson JO, et al. A reduction in emergency department use by children from a parent educational intervention. Fam Med 2011;43:106-11.

32. Roberts CR, Imrey PB, Turner JD, et al. Reducing physician visits for colds through consumer education. JAMA 1983;250:1986-9.

33. Plass AM, Timmermans DR, van der Wal G. Decreasing the number of consultations for minor illnesses of Turkish and Dutch inhabitants of a deprived area in the Netherlands: an intervention study. Fam Pract 2005;22:51-7.

34. Little $\mathrm{P}$, Stuart B, Francis N, et al. Effects of internet-based training on antibiotic prescribing rates for acute respiratory-tract infections: a multinational, cluster, randomised, factorial, controlled trial. Lancet 2013;382:1175-82.

35. Dixon-Woods M. Writing wrongs? An analysis of published discourses about the use of patient information leaflets. Soc Sci Med 2001;52:1417-32.

36. Ferguson LA, Pawlakm R. Health literacy: the road to improved health outcomes. J Nurse Pract 2011;7:123-9.

37. Watson PW, McKinstry B. A systematic review of interventions to improve recall of medical advice in healthcare consultations. J $R$ Soc Med 2009;102:235-43. 